\title{
O QUE OS OLHOS NÃO VÊEM...
}

Tatyanna Ramos Barreira é formada em Letras pela UERJ e pós-graduada pela UGF. E-mail: taty1309@hotmail.com

O oriental resolveu conhecer o mundo. Key lam Sahara aos 54 anos desconhecia outros povos; no entanto, era perito em máquinas. Acreditava que dos amigos não precisava. Café da manhã em pé no trem, almoço na fábrica, jantar em seu apartamento solitário; no restante do horário, trabalhava. Medalhas, certificados e diplomas eram o adorno das paredes de sua casa.

Chegou ao Brasil, no aeroporto, um brasileiro lhe perguntou seu nome - mas Key jamais falava outra língua que não fosse a sua de origem e o inglês (afinal, para ser um excelente funcionário, isso lhe era exigido). Então, o brasileiro resolveu fazer mímicas e o oriental desconfiado de tamanho interesse do nativo em comunicar-se, foi embora para o hotel. Ao descer do táxi, o motorista, ao receber a quantia devida, estendeu-lhe a mão (pensou que aquele homem queria firmar um negócio com ele ou queria algo sexual); fingiu não ter visto e saiu do táxi.

Em seu primeiro dia, saiu a observar o desconhecido país. Era mais sujo que o seu, os transportes eram desorganizados, crianças berravam pelas ruas e em restaurantes. Estranhou tudo. Contudo, à noite, resolveu ir a um lugar em que havia várias pessoas reunidas e extremamente felizes. Ficou um tempo por lá, notou que todas observavam a televisão atentamente e tomavam um líquido amarelo. Quis ser igual... não sabia se era o local, a bebida ou as pessoas, mas algo ali parecia interessante. Pediu uma cerveja com toda a dificuldade que a língua the impunha (foi auxiliado por um brasileiro camarada). O local foi ficando apertado, pessoas encostavam no oriental sem pedir permissão. Em um dado momento, quando na televisão uma bola entrou em uma trave esbranquiçada, todos gritavam muito; sentiu-se incomodado. Após alguns segundos gritando, a mulher ao seu lado Ihe abraçou. Gostou daquele afeto. A língua deixou de ser um empecilho e passou a ser sua aliada. Nunca mais voltou ao seu país. Key lam Sahara vive há 10 dez anos no Brasil e a aquele fora o primeiro de muitos abraços. 